\title{
OPEN A novel bis(pyrazolyl)methane compound as a potential agent against Gram-positive bacteria
}

\author{
Pedro Seguí1,2, John J. Aguilera-Correa ${ }^{3}$, Elena Domínguez-Jurado ${ }^{4,5}$, \\ Christian M. Sánchez-López ${ }^{6,7}$, Ramón Pérez-Tanoira ${ }^{8,9}{ }^{,}$Ana V. Ocaña ${ }^{2}$, \\ José A. Castro-Osma ${ }^{4,5}$, Jaime Esteban ${ }^{3}$, Antonio Marcilla ${ }^{6,7}$, Carlos Alonso-Moreno ${ }^{4,5}$, \\ Francisco C. Pérez-Martínez ${ }^{2 \bowtie}$ \& Milagros Molina-Alarcón ${ }^{2,10}$
}

This study was designed to propose alternative therapeutic compounds to fight against bacterial pathogens. Thus, a library of nitrogen-based compounds bis(triazolyl)methane (1T-7T) and bis(pyrazolyl)methane (1P-11P) was synthesised following previously reported methodologies and their antibacterial activity was tested using the collection strains of Staphylococcus aureus, Enterococcus faecalis, Escherichia coli, and Pseudomonas aeruginosa. Moreover, the novel compound 2P was fully characterized by IR, UV-Vis and NMR spectroscopy. To evaluate antibacterial activity, minimal inhibitory concentrations (MICs), minimal bactericidal concentrations (MBCs), minimum biofilm inhibitory concentrations (MBICs), and minimum biofilm eradication concentrations (MBECs) assays were carried out at different concentrations $(2-2000 \mu \mathrm{g} / \mathrm{mL}$ ). The MTT assay and Resazurin viability assays were performed in both human liver carcinoma HepG2 and human colorectal adenocarcinoma Caco-2 cell lines at $48 \mathrm{~h}$. Of all the synthesised compounds, $2 \mathrm{P}$ had an inhibitory effect on Gram-positive strains, especially against S. aureus. The MIC and MBC of 2P were 62.5 and $2000 \mu \mathrm{g} / \mathrm{mL}$ against $S$. aureus, and 250 and $2000 \mu \mathrm{g} / \mathrm{mL}$ against $E$. faecalis, respectively. However, these values were $>2000 \mu \mathrm{g} / \mathrm{mL}$ against $E$. coli and $P$. aeruginosa. In addition, the MBICs and MBECs of $2 \mathrm{P}$ against $S$. aureus were 125 and $>2000 \mu \mathrm{g} / \mathrm{mL}$, respectively, whereas these values were $>2000 \mu \mathrm{g} /$ $\mathrm{mL}$ against $E$. faecalis, E. coli, and $P$. aeruginosa. On the other hand, concentrations up to $250 \mu \mathrm{g} / \mathrm{mL}$ of 2P were non-toxic doses for eukaryotic cell cultures. Thus, according to the obtained results, the 2P nitrogen-based compound showed a promising anti-Gram-positive effect (especially against $S$. aureus) both on planktonic state and biofilm, at non-toxic concentrations.

Despite of several emerging antibiotic families effective against pathogenic bacteria existing ${ }^{1,2}$, strains resistant to current therapeutic options have become one of the most important challenges in this field. Indeed, antibioticresistant strains have been identified between both Gram-positive and Gram-negative bacteria ${ }^{3,4}$ with extraordinarily high mortality and morbidity rates worldwide ${ }^{1,5}$. To date, these infections are treated with different combinations of antibiotics, but they can produce severe undesired side effects ${ }^{6}$.

Antibiotic resistances are considered a worrying economic burden that leads to an estimated extra annual cost of $\$ 2.2$ billion in the United States alone ${ }^{7}$. The risk and cost related to bacterial resistance to chemical products have drawn interest in discovering new compounds with antimicrobial effects ${ }^{8,9}$. In this field, the chemistry of metallic ions, enzybiotics, natural extracts or new nanotechnology-based delivery systems are leading research lines ${ }^{10,11}$.

\footnotetext{
${ }^{1}$ Department of Otorhinolaryngology, Complejo Hospitalario Universitario, 02006 Albacete, Spain. ${ }^{2}$ Instituto de Investigación en Discapacidades Neurológicas (IDINE), University of Castilla-La Mancha, 02001 Albacete, Spain. ${ }^{3}$ Clinical Microbiology Department, IIS-Fundacion Jimenez Diaz-UAM, 28040 Madrid, Spain. ${ }^{4}$ NanoCRIB Unit, Centro Regional de Investigaciones Biomédicas, 02008 Albacete, Spain. ${ }^{5}$ School of Pharmacy, University of Castilla-La Mancha, 02008 Albacete, Spain. ${ }^{6}$ Department of Farmàcia i Tecnologia Farmacèutica i

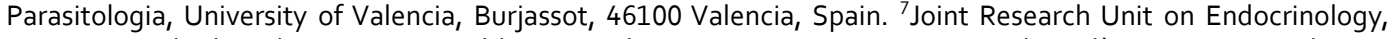
Nutrition and Clinical Dietetics, Health Research Institute La Fe-Universitat de València, 46026 Valencia, Spain. ${ }^{8}$ Clinical Microbiology Department, Hospital Universitario Príncipe de Asturias, Madrid, Spain. ${ }^{9}$ Biomedicine and Biotechnology Department, School of Medicine, University of Alcalá de Henares, Madrid, Spain. ${ }^{10}$ Department of Nursing, University of Castilla-La Mancha, 02071 Albacete, Spain. ${ }^{\bowtie}$ email: franciscocarlos.perez@gmail.com
} 


\section{Bis(pyrazoyl)methane nitrogen-based derivates}<smiles>Cc1cc(C)n(Cn2nc(C)cc2C)n1</smiles>

(1P)<smiles>Cc1cc(C)n(C(Cc2ccc(C(C)C)cc2)n2nc(C)cc2C)n1</smiles>

(2P)<smiles>Cc1cc(C)n(C(c2ccccc2)C(c2ccccc2)(c2ccccc2)n2nc(C)cc2C)n1</smiles>

(3P)<smiles>Cc1cc(C)n(C(CC(C)(C)C)C(O)C2CC3CCC2(C)C3)n1</smiles>

(4P)<smiles>Cc1cc(C)n(C(C(=O)NC(C)c2ccccc2)n2nc(C)cc2C)n1</smiles>

(5P)<smiles></smiles><smiles>Cc1cc(C)n(C(C(=S)Nc2ccccc2)n2nc(C)cc2C)n1</smiles>

(7P)<smiles>Cc1ccn(C(C(=S)Nc2cccc3ccccc23)n2nc(C)cc2C)n1</smiles>

(8P)<smiles>Cc1cc(C)n(C(C(=O)Nc2ccc3c(c2)Cc2ccccc2-3)n2nc(C)cc2C)n1</smiles>

(9P)

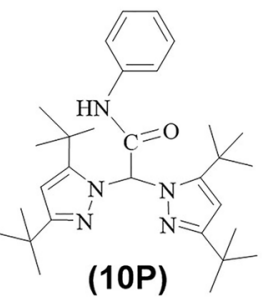

(10P)

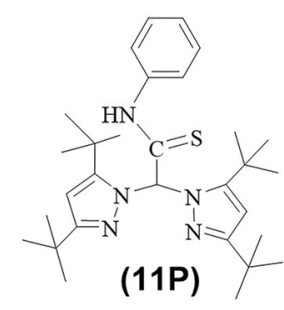

\section{Bis(triazolyl)methane-based nitrogen derivates}

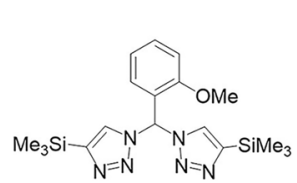

(1T)

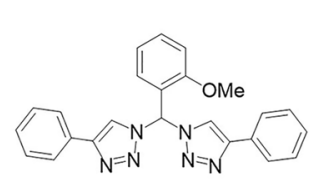

(2T)

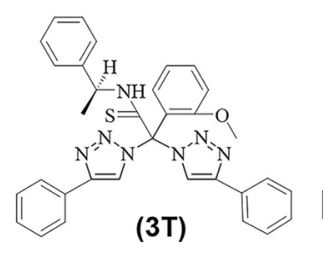

(3T)

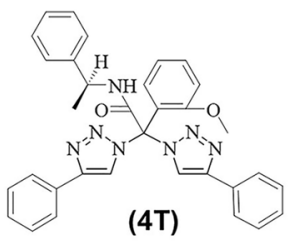

(4T)

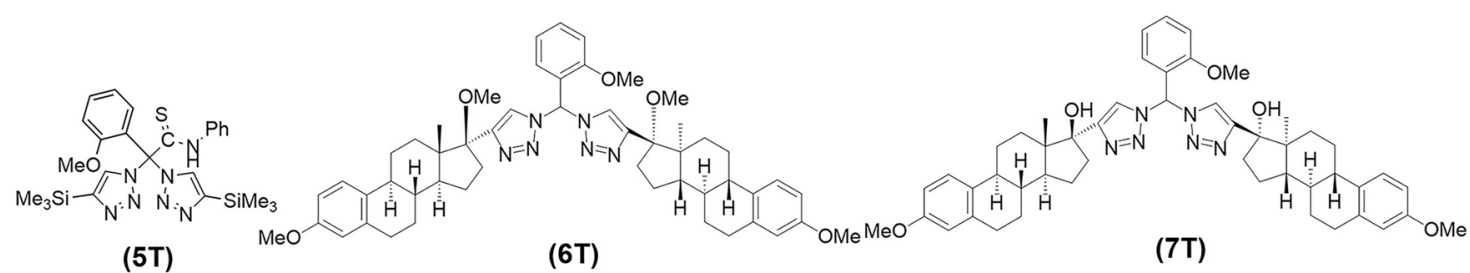

(5T)

(6T)
(6P)

Figure 1. Chemical structures of both series of compounds.

On other hand, bacteria can exist in two non-excluding lifestyles: planktonic or free-life form, or in a sessile form named biofilm. A biofilm is a bacterial aggregate embedded in a self-produced exopolymeric matrix where numerous and complex sociomicrobiological interactions rule ${ }^{12}$. Biofilm of a bacterium exhibits different inherent characteristics that confer it resistance to almost any unfavorable condition (e.g. the attack of the immune system) and antibacterial compounds, such as antibiotics, reactive oxygen species, and heavy metals. Therefore, if the growth of any bacterium is inhibited or completely prevented, the development of the biofilm of such bacterium is also prevented ${ }^{13}$. In this regard and with the aim to prevent antibiofilm formation, the development of quorum sensing inhibitors have been one of the most promising strategy ${ }^{14-16}$.

Bis(triazolyl)methane and bis(pyrazolyl)methane-based nitrogen compounds have been previously used as auxiliary tridentate ligands for the synthesis of organometallic compounds ${ }^{17}$. These counterparts have been extensively employed as catalysts for polymerisation, epoxidation and oxidation processes ${ }^{18}$. From a chemical point of view, the comparatively rapid and modular synthesis of bis(triazolyl)methane ${ }^{19}$ and bis(pyrazoyl) methane ${ }^{20}$ nitrogen-based scaffolds present an ideal template for both high-throughput and rational drug design. Moreover, the potential utility of this family of compounds as an easily tunable core in both rapid drug discovery and subsequent logical designs of new antibacterial metal-containing drugs remains unknown ${ }^{21}$.

This study was conducted to screen bis(triazolyl)methane and bis(pyrazolyl)methane derivatives as compounds with antibacterial activity against both planktonic and biofilm states.

\section{Results}

Synthesis and characterisation of the bis(triazolyl)methane and bis(pyrazolyl)methane deriv-

atives. Most of the compounds herein used were synthesised according to previously published procedures (see the chemical structures in Fig. 1) ${ }^{19,20,22}$. Briefly, 1T-7T were obtained by reaction between readily accessible alkynes and geminal diazides in a double $\mathrm{Cu}$-catalyzed azide-alkyne cycloaddition reaction. The compounds $1 \mathrm{P}-11 \mathrm{P}$ were previously obtained from the corresponding lithium salts and subsequent hydrolysis by 


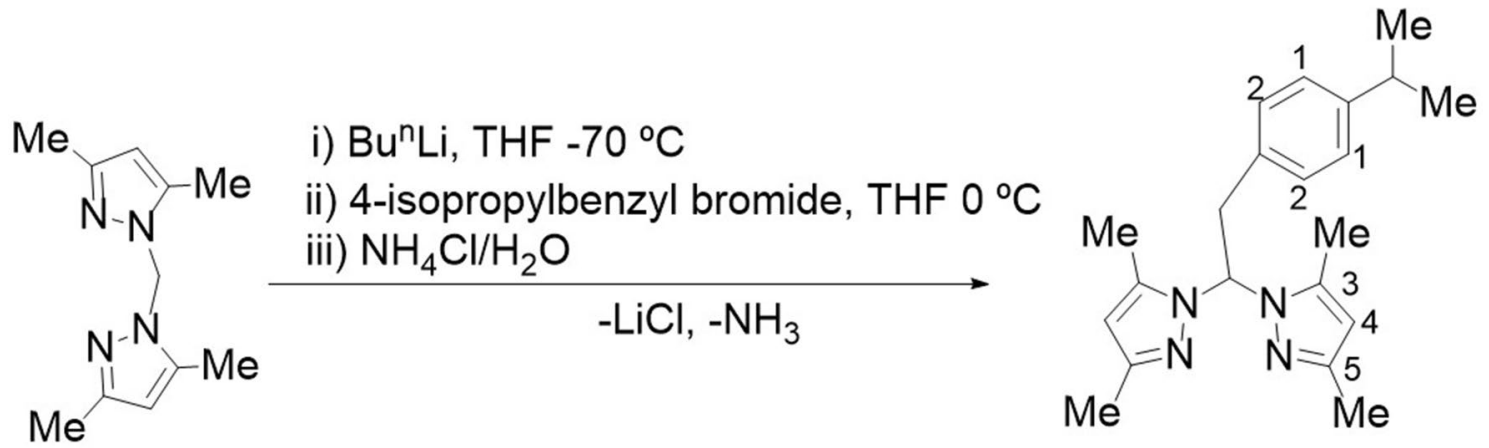

Figure 2. Synthetic route for compound 2P.

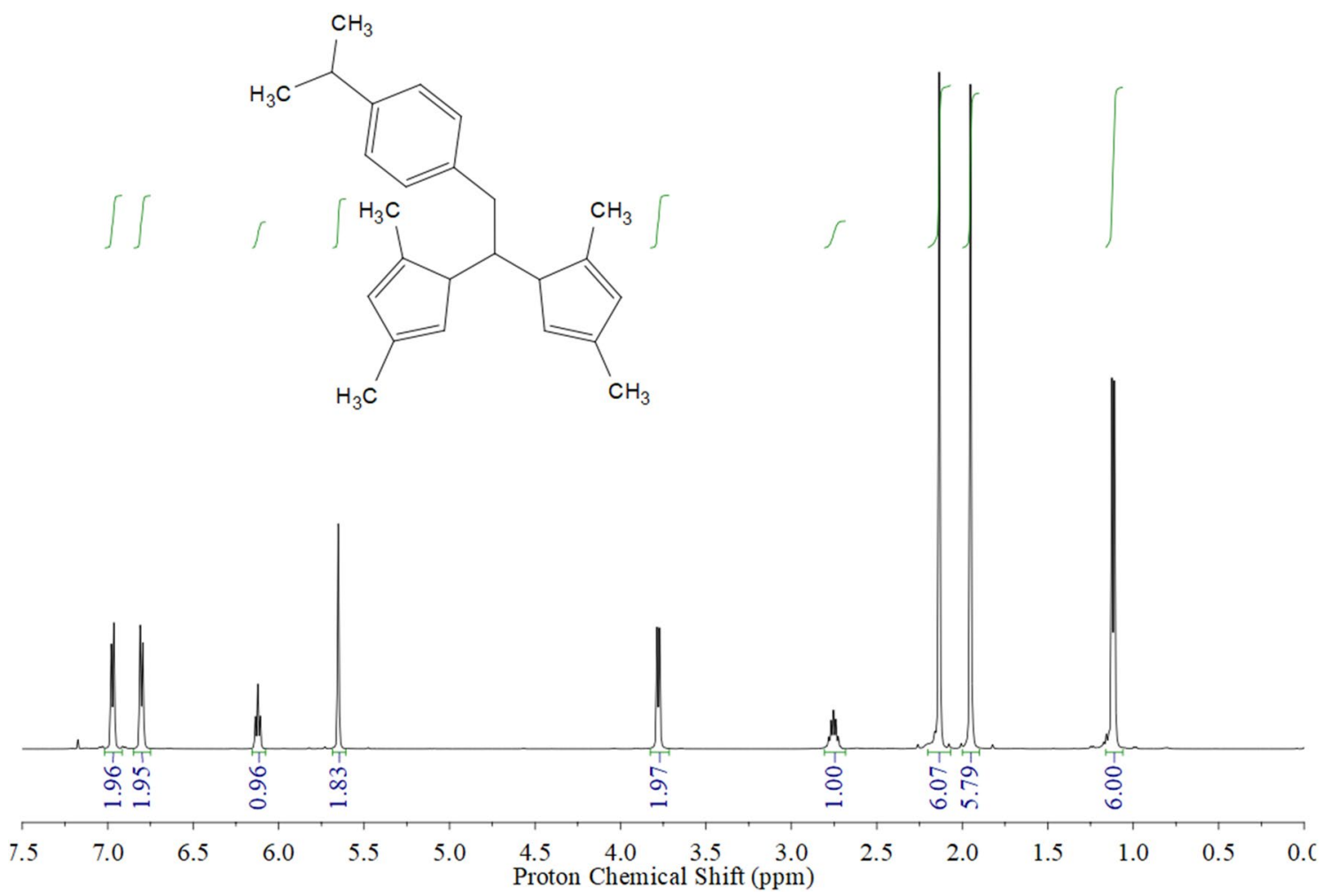

Figure 3. ${ }^{1} \mathrm{H}-\mathrm{NMR}$ spectrum for the $2 \mathrm{P}$ compound in $\mathrm{CDCl}_{3}$ at $297 \mathrm{~K}$.

saturated aqueous ammonium chloride solutions. In particular, the novel compound $2 \mathrm{P}$ was obtained as a pale yellow solid by one-pot reaction of bis(3,5-dimethylpyrazol-1-yl)methane with $\mathrm{nBuLi}$, followed by the addition of 4 -isopropylbenzyl bromide to THF at $0{ }^{\circ} \mathrm{C}$ (Fig. 2). The compounds $1 \mathrm{~T}-7 \mathrm{~T}$ and $1 \mathrm{P}-11 \mathrm{P}$ were not soluble in water but air stable and soluble in chlorinated solvents. Qualitative tests determined that the compounds are soluble in polar protic solvents such as methanol, and ethanol, and polar aprotic solvents such as dimethyl sulfoxide and tetrahydrofuran.

The 2P nitrogen-based compound characterisation was carried out by IR, UV and NMR spectroscopy (Fig. 3 and Fig. S1-S4 in the Supporting Information). Structural elucidation is depicted in the "Methods" section and illustrated by the ${ }^{1} \mathrm{H}-\mathrm{NMR}$ spectrum in Fig. 3. In the IR spectrum of $2 \mathrm{P}$ (solid state), the $\mathrm{C}=\mathrm{N}$ functional group was depicted by a broad band at $1378 \mathrm{~cm}^{-1}$, while the strong absorption at $1019 \mathrm{~cm}^{-1}$ was attributed to the in-plane bending vibration of pyrazole moiety. The ${ }^{1} \mathrm{H}$ and ${ }^{13} \mathrm{C}-\left\{{ }^{1} \mathrm{H}\right\}$ NMR spectra of $2 \mathrm{P}$ contained a single set of resonances for pyrazole rings, which indicates that the two pyrazole rings were equivalents. The ${ }^{1} \mathrm{H}_{-}{ }^{13} \mathrm{C}$ heteronuclear correlation ( $\mathrm{g}$-HSQC) experiments enabled us to assign the resonances corresponding to $\mathrm{C}^{4}, \mathrm{Me}^{3}$ and $\mathrm{Me}^{5}$ of the pyrazole ring (see "Methods" and Fig. S2 in the Supporting Information). The presence of signals at 1.12 and $2.70 \mathrm{ppm}$ and at 24 and $33 \mathrm{ppm}$ in the ${ }^{1} \mathrm{H}$ and ${ }^{13} \mathrm{C}\left\{{ }^{1} \mathrm{H}\right\}$ NMR spectra of $2 \mathrm{P}$, respectively, confirmed that isopropylbenzyl moiety was present in the compound.

Antibacterial assessments. The antibacterial effect of the compounds was evaluated by studying both MICs and MBCs. For this purpose, the different compounds were studied against planktonic bacteria of $S$. aureus, E. faecalis, E. coli, and P. aeruginosa at different concentrations. Except for the $2 \mathrm{P}$ compound, none of 
a.

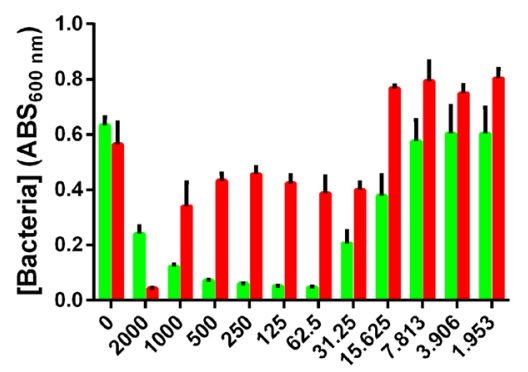

[2P] $(\mu \mathrm{g} / \mathrm{mL})$

c.

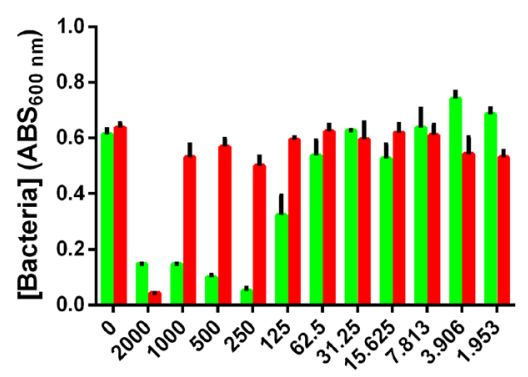

[2P] $(\mu \mathrm{g} / \mathrm{mL})$

e.

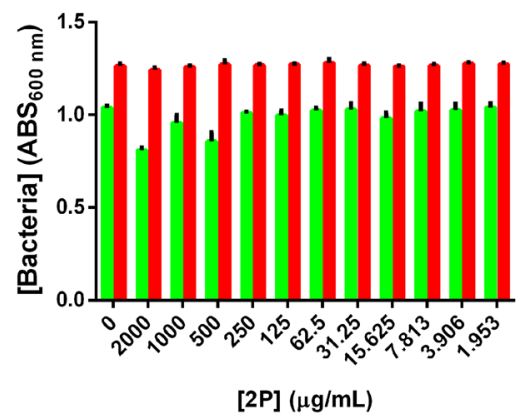

g.

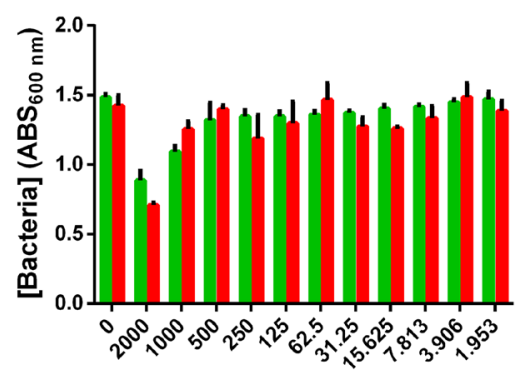

[2P] $(\mu \mathrm{g} / \mathrm{mL})$ b.

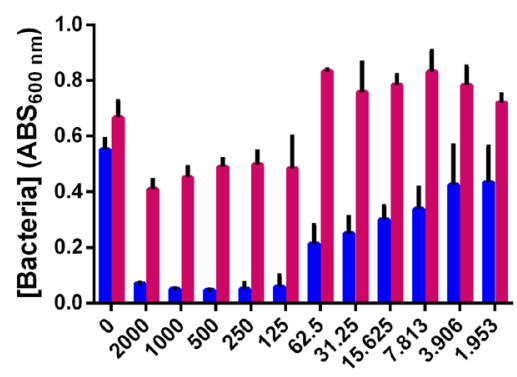

$[2 \mathrm{P}](\mu \mathrm{g} / \mathrm{mL})$

d.

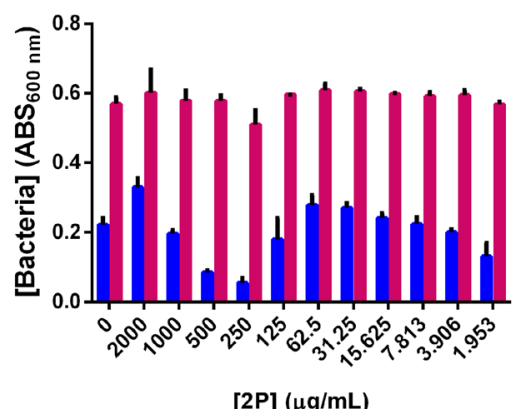

f.

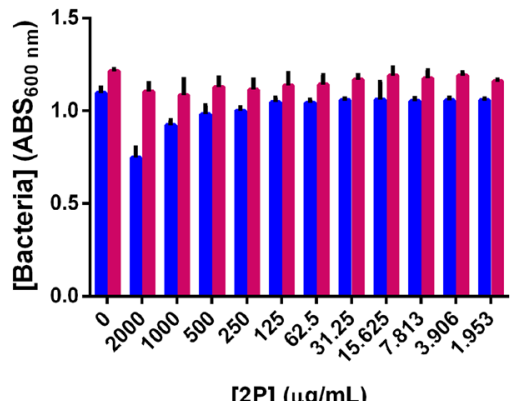

h.

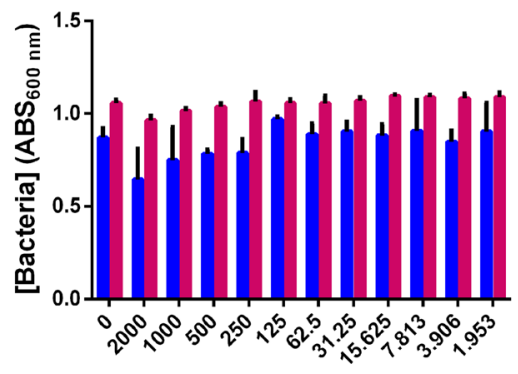

[2P] $(\mu \mathrm{g} / \mathrm{mL})$

Figure 4. Minimal inhibitory concentrations (MICs, green) and minimal bactericidal concentrations (MBCs, red) (a,c,e,g), as well as minimal biofilm inhibitory concentrations (MBICs, blue) and minimal biofilm eradication concentrations (MBECs, magenta) (b,d,f,h) of $2 \mathrm{P}$ against $S$. aureus $(\mathbf{a}, \mathbf{b})$, E. faecalis (c,d), E. coli (e,f), and $P$. aeruginosa $(\mathbf{g}, \mathbf{h})$. Bars represent the interquartile range. $A B S$ absorbance. 
a)

Caco-2

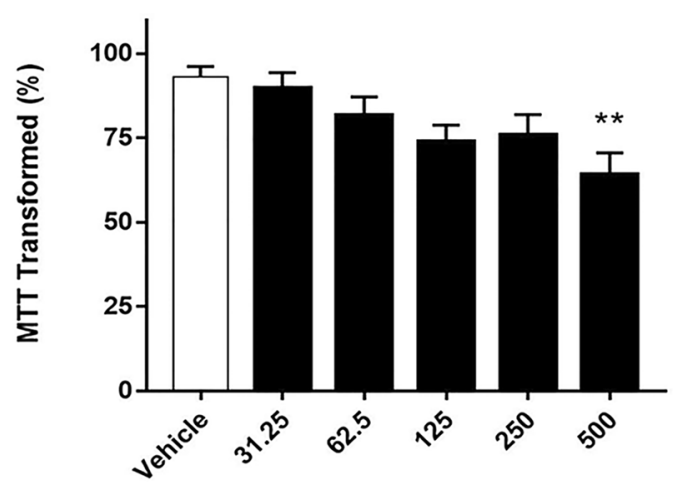

2P Concentration $(\mu \mathrm{g} / \mathrm{mL})$

c)

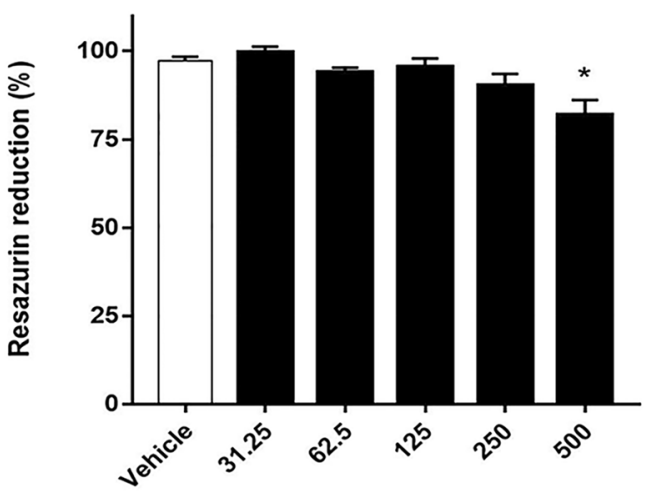

2P Concentration ( $\mu \mathrm{g} / \mathrm{mL})$ b)

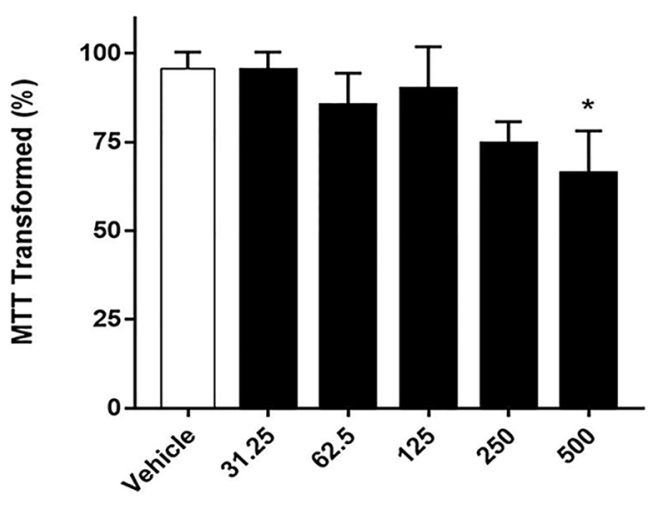

2P Concentration $(\mu \mathrm{g} / \mathrm{mL})$

d)

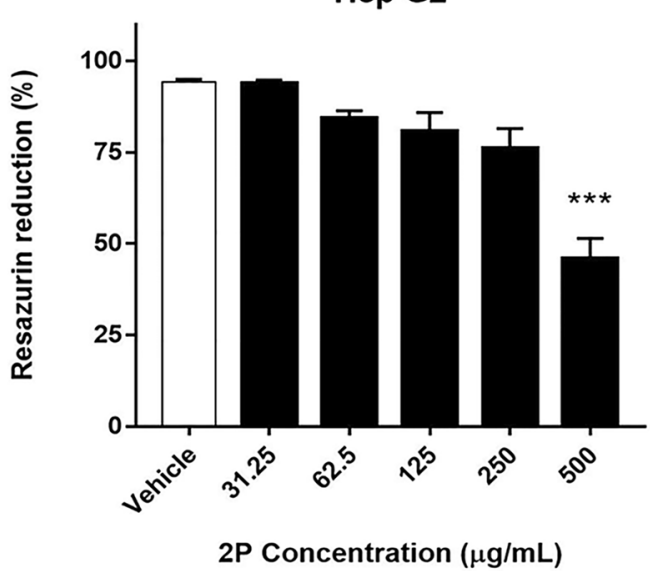

Figure 5. Evaluation of cytotoxicity induced by the 2P nitrogen-based compound. Cytotoxicity was determined by either the percentage of $(\mathbf{a}, \mathbf{b})$ MTT transformed or $(\mathbf{c}, \mathbf{d})$ Resazurin reduction detected in the HepG2 and Caco-2 cells exposed to concentrations from 500 to $31.25 \mu \mathrm{g} / \mathrm{mL}$ of the 2P derivative in MTT and Resazurin assays. The $2 \mathrm{P}$ compound reduced cell viability in a concentration-dependent manner, with no cytotoxicity detected up to $500 \mu \mathrm{g} / \mathrm{mL}$ compared to the untreated control cells. Data are expressed as mean $\pm \operatorname{SEM}(n=5)$. ${ }^{*} \mathrm{p}<0.05 ;{ }^{* *} \mathrm{p}<0.01 ;{ }^{* * *} \mathrm{p}<0.001$ vs. the vehicle-treated cells (using Kruskal-Wallis followed by Dunn's test).

the compounds showed any activity against the studied bacteria. The MIC and MBC of $2 \mathrm{P}$ were found to be 62.5 and $2000 \mu \mathrm{g} / \mathrm{mL}$ against S. aureus (Fig. 4a), and 250 and $2000 \mu \mathrm{g} / \mathrm{mL}$ against $E$. faecalis (Fig. $4 \mathrm{c}$ ), respectively. The MICs and MBCs of $2 \mathrm{P}$ against E. coli (Fig. $4 \mathrm{e}$ ) and P. aeruginosa (Fig. $4 \mathrm{~g}$ ) were $>2000 \mu \mathrm{g} / \mathrm{mL}$ for both of them.

In addition, the antibiofilm effect of compounds was evaluated by studying both MBICs and MBECs. For this purpose, the different compounds were tested against biofilms S. aureus, E. faecalis, E. coli, and P. aeruginosa at different concentrations. As observed against the planktonic bacterial strains, only the $2 \mathrm{P}$ derivative had antibiofilm effects. Thus the MBICs and MBECs of $2 \mathrm{P}$ against S. aureus were $125 \mathrm{and}>2000 \mu \mathrm{g} / \mathrm{mL}$, respectively (Fig. 4b). The MBICs and MBECs of $2 \mathrm{P}$ against E. faecalis (Fig. 4d), E. coli (Fig. 4f) and P. aeruginosa (Fig. 4h) were $>2000 \mu \mathrm{g} / \mathrm{mL}$ for both of them (Fig. 4b). However, E. coli and P. aeruginosa showed a slight, but significant, drop in the bacterial concentration in MICs and MBICs at $2000 \mu \mathrm{g} / \mathrm{mL}$.

Cytotoxicity of the 2P derivative. In order to examine the toxicity caused by the $2 \mathrm{P}$ compound on the human liver carcinoma Hep G2 and human colorectal adenocarcinoma Caco-2 cell lines, the MTT assay or Resazurin viability assays were performed. The cell viability of Hep G2 cells at the 500, 250, 125, 62.5 and $31.25 \mu \mathrm{g} /$ $\mathrm{mL}$ concentrations of $2 \mathrm{P}$ was $45.82 \pm 12.57,76 \pm 12.3,80.71 \pm 11.55,84.15 \pm 5.03$ and $93.68 \pm 2.31$, respectively, in the Resazurin assays, and $66.07 \pm 26.95,74.54 \pm 13.73,89.91 \pm 26.55,85.28 \pm 20.31$ and $95.13 \pm 11.64$ in the MTT assay (Fig. 5). The cell viability of Caco-2 cells was $81.89 \pm 9.54,90.29 \pm 7.28,95.41 \pm 5.54,94.06 \pm 2.69$ and $99.57 \pm 3.83$ in the Resazurin assay, and $63.98 \pm 14.88,75.79 \pm 13.64,73.83 \pm 11.25,81.68 \pm 12.35$ and $89.6 \pm 10.71$ in the MTT assay, respectively (Fig. 5).

The results showed that the studied derivative with bactericidal properties (2P) reduced the cell viability in both cell lines in a concentration-dependent manner, and no significant reduction in cell viability was observed up to $500 \mu \mathrm{g} / \mathrm{mL}$ of $2 \mathrm{P}$ compared to the untreated control cells (Fig. 5). The cytotoxic $2 \mathrm{P}$ concentrations (500 $\mu \mathrm{g} /$ 
$\mathrm{mL}$ ) led to changes in cell morphology, as observed by microscopic observations (Fig. S3 in the Supporting Information). Our results revealed that Hep G2 cells seemed to be more susceptible than Caco-2 cells to high $2 \mathrm{P}$ derivative concentrations.

$\mathrm{pH}$ measurements. In our study, the $2 \mathrm{P}$ compound induced a slight culture media alkalinisation in a timecourse manner. Thus, in contrast to the results obtained with vehicle, the presence of $2 \mathrm{P}$ at a high dose $(500 \mu \mathrm{g} /$ $\mathrm{mL}$ ) in the culture medium increased the $\mathrm{pH}$ from $7.50 \pm 0.03$ at $0 \mathrm{~h}$ to $7.62 \pm 0.01,7.82 \pm 0.01,7.99 \pm 0.02$, and $8,12 \pm 0.01$ at $6 \mathrm{~h}, 24 \mathrm{~h}, 48 \mathrm{~h}$, and $72 \mathrm{~h}$ of incubation, respectively. This increment was statistically significant only after $48 \mathrm{~h}$ and $72 \mathrm{~h}$ of incubation, compared to vehicle-treated media $(\mathrm{P}=0.049$ and 0.037 , respectively; Mann-Whitney test).

\section{Discussion}

As resistance to antimicrobial agents by pathogenic bacteria has emerged in recent years, new compounds with antimicrobial effects have come to the forefront ${ }^{9,23}$. The main aim of the present study was to assess the antimicrobial activity of a series of bis(triazolyl)methane and bis(pyrazolyl)methane nitrogen-based compounds. After evaluating 18 different compounds, $2 \mathrm{P}$ was identified as a new derivative with significant activity against bacterial growth and/or biofilm formation at non-toxic doses for eukaryotic cells in culture. This compound and its full characterisation are herein reported for the first time.

Compound $2 \mathrm{P}$ displayed the ability to inhibit the bacterial growth of both $S$. aureus at $62.5 \mu \mathrm{g} / \mathrm{mL}$ and E. faecalis at $250 \mu \mathrm{g} / \mathrm{mL}$, which are two clinically important Gram-positive bacteria. 2P also reduced S. aureus biofilm formation, and the MICs and MBICs of S. aureus were lower than the cytotoxic $2 \mathrm{P}$ concentration studied by MTT and Resazurin viability assays in both human liver carcinoma Hep G2 and human colorectal adenocarcinoma Caco- 2 cell lines. The mechanism of the antimicrobial effect shown by $2 \mathrm{P}$ on Gram-positive bacteria is unclear, but its antimicrobial properties are probably based on several factors, including high $\mathrm{pH}$ and osmotic effects caused by the non-physiological concentration of dissolved ions, as observed with other compounds ${ }^{24-26}$. However, at high doses, a lytic effect on bacteria was also observed when the $2 \mathrm{P}$ nitrogen-based compound was used.

$S$. aureus as a type of Gram-positive bacterium was analyzed because it is one of the most frequent pathogens worldwide ${ }^{27,28}$. E. coli is a Gram-negative bacterium that usually affects older patients, and is the most frequent Gram-negative microorganism related to pathogenic infections ${ }^{29,30}$. Finally, E. faecalis and P. aeruginosa are clinically relevant Gram-positive and Gram-negative bacteria, respectively, whose presence is associated with infections in many patients ${ }^{28}$.

It is the first time that the antibacterial effects of $2 \mathrm{P}$ are reported, with MICs ranging from $125 \mu \mathrm{g} / \mathrm{mL}$ to over $1 \mathrm{mg} / \mathrm{mL}$. Depending on the microbial strain and type of antimicrobial assay followed. $2 \mathrm{P}$ was generally more effective against Gram-positive than Gram-negative bacteria, perhaps due to differences in bacterial cell wall composition. Indeed, the $2 \mathrm{P}$ compound had a stronger effect against $S$. aureus Gram-positive surfaces, whose walls exhibited more negative charges than the other studied bacterial strains. However, other mechanisms cannot be ruled out. Recently, there was a report about several compounds possibly inactivating bacterial growth through multitarget effects due to cell membrane disruption and subsequent cell lysis, and also due to respiratory activity inhibition $^{31}$. Besides, as the repair of sublethal injuries is associated with high energy production to regain the repair membrane damage ability ${ }^{32}$, the continuous depletion of the energy pool could also be responsible for $2 \mathrm{P}$ antibacterial effects on Gram-positive bacteria.

The generally good efficacy of the 2P compound against Gram-positive bacteria (S. aureus and E. faecalis) compared to Gram-negative ones (E. coli and P. aeruginosa) could be especially relevant because of the differences in membrane structure and peptidoglycan layer thickness ${ }^{30,33}$. The peptidoglycan layer of the membranes of Gram-positive bacteria (about 20-80 nm) is usually thicker than that of Gram-negative bacteria (about 7-8 nm $)^{34}$, which makes it more difficult to penetrate and, thus, new compounds like $2 \mathrm{P}$ that can properly kill this kind of bacteria are very interesting. The thicker $S$. aureus membrane structure may hinder most of the compounds penetrating to the cell wall, which would reduce its toxic effects on such bacteria ${ }^{35}$. However, the $2 \mathrm{P}$ derivative could bind to Gram-positive bacteria cell walls and cause membrane disruption through direct interactions or by a lytic effect, which occurred when $2 \mathrm{P}$ was applied at high concentrations. This action mechanism should be less toxic in mammalian cells because these cells can degrade chemical ligands by lysosomal fusion to reduce toxicity and free radical damage ${ }^{36}$. In addition, other factors related to the antibacterial effects of the 2P compound on Gram-positive bacteria could be the increased osmotic pressure caused by ions that could be released from $2 \mathrm{P}$, which would perturb the membrane potential of bacteria ${ }^{26}$, although this action mechanism should be analyzed in more depth.

2P also had inhibitory effects on $S$. aureus biofilm development, as we noted in the MBIC and MBEC assays. Although one of the implicated mechanisms has to be due to the antimicrobial activity against planktonic cells, the $S$. aureus antibiofilm effect could also result from the modification to $\mathrm{pH}$ during the incubation time with the $2 \mathrm{P}$ compound. Even though $S$. aureus is able to grow in a range of $\mathrm{pH} 4.0-9.8$, with an optimum $\mathrm{pH}$ of 6-7, an alkaline environment is not well tolerated by microorganisms $\mathrm{s}^{37}$ and could interfere with the $S$. aureus biofilm by reducing it or inhibiting its growth ${ }^{38}$.

This study firstly showed the effect of the $2 \mathrm{P}$ nitrogen-based compound on Gram-positive bacterial strains. However, further experiments should be performed to evaluate whether this compound had a straight effect on bacterial adhesion mechanisms or only on bacterial viability. Other experiments should also be run to evaluate $2 \mathrm{P}$ activity using clinical strains isolated from patients because they often show different properties compared to laboratory-adapted collection strains ${ }^{39}$. 


\section{Conclusion}

Pyrazoline derivatives have been widely used as pharmacophores in medicinal chemistry. In this very context, some studies confirmed their antimicrobial activity ${ }^{40}$. On the other hand, triazole derivatives emerged for the treatment of many systemic mycoses ${ }^{41,42}$. Of note, fluconazole as a triazole fungistatic agent. Based on those structures, a family of pyrazole and triazole-core compounds were synthetized and their antibacterial activity was tested against strains of S. aureus, E. faecalis, E. coli, and P. aeruginosa. Considering all the results obtained from antimicrobial screen, the $2 \mathrm{P}$ nitrogen-based compound is identified as a derivative with anti-Gram-positive activity and low toxicity to eukaryotic cells. Effects include an inhibitory effect on bacterial growth and biofilm formation, mainly on S. aureus. Based on the compounds structure, it seems that the p-cymene substitution on the pyrazole core has made a crucial contribution to the antimicrobial activity in this series of pyrazole derivatives $1 \mathrm{P}-11 \mathrm{P}$. In fact, p-cymene is a monoterpene that shows a range of biological activity including antioxidant, anti-inflammatory, antinociceptive, anxiolytic, anticancer and antimicrobial effects ${ }^{24}$. Further studies with clinical isolates are necessary to show if $2 \mathrm{P}$ is a suitable candidate to develop new agents with antibacterial properties.

\section{Methods}

Chemicals. All manipulations were performed under nitrogen by standard Schlenk techniques ${ }^{43}$. THF was pre-dried over sodium wire and distilled under nitrogen from sodium. $\mathrm{CDCl}_{3}$ was stored over activated $4 \AA$ molecular sieves and degassed by several freeze-thaw cycles. All the NMR experiments were conducted in deuterated solvents at $297 \mathrm{~K}$ in a Varian FT-400 spectrometer. The ${ }^{1} \mathrm{H} \pi / 2$ pulse length was adjusted per sample. The ${ }^{1} \mathrm{H}$ - and ${ }^{13} \mathrm{C}\left\{{ }^{1} \mathrm{H}\right\}$-NMR chemical shifts $(\delta)$ were expressed as ppm in relation to TMS. Coupling constants (J) were documented in $\mathrm{Hz}$. Two-dimensional NMR spectra were acquired with standard VARIAN-FT software and processed on an IPC-Sun computer. The solvent signals were used as references and chemical shifts were converted into the TMS scale. Melting points (m.p.) were determined using a melting point block (SMP 10). The sample was heated to $100^{\circ} \mathrm{C}$ and then heated at a rate of $1^{\circ} \mathrm{C} / \mathrm{min}$ to $275^{\circ} \mathrm{C}$. The IR experiments were conducted on FT/IR-4000 Series Jasco Instruments. The UV-Vis absorption spectra were recorded at room temperature by a Cary 100 (Varian) spectrophotometer using a slit width of $0.4 \mathrm{~nm}$ and a scan rate of $600 \mathrm{~nm} / \mathrm{min}$.

Synthesis of bis(triazolyl)methane and bis(pyrazolyl)methane-based nitrogen compounds. Bis(Triazolyl)methane derivatives (1T-7T) were prepared by a reaction between alkynes and geminal dizides in double-coupled Cu-catalysed azide-alkyne cycloaddition reactions as previously reported ${ }^{19}$. Compound bis(3,5-dimethylpyrazol-1-yl)methane (1P) was prepared according to procedures reported in the literature ${ }^{44}$. Bis(pyrazolyl)methane derivatives (3P-11P) were obtained by a one-pot reaction of bis(3,5-dimethylpyrazol-1-yl)methane (bdmpzm) or bis(3,5-di-tert-butylpyrazol-1-yl)methane with $\mathrm{Bu}^{\mathrm{n}} \mathrm{Li}$, followed by the addition of the corresponding isocyanates or isothiocyanates to provide the desired compounds ${ }^{22}$.

For the $2 \mathrm{P}$ compound synthesis, bis(3,5-dimethylpyrazol-1-yl)methane $(2.00 \mathrm{~g}, 9.77 \mathrm{mmol})$ was dissolved in dry THF $(50 \mathrm{~mL})$ in a $250 \mathrm{~mL}$ Schlenk tube and cooled to $-78^{\circ} \mathrm{C}$. Then $1.6 \mathrm{M}$ solution of $\mathrm{Bu} \mathrm{u}^{\mathrm{n}} \mathrm{Li}(6.11 \mathrm{~mL}$, $9.77 \mathrm{mmol}$ ) in hexane was added dropwise and the mixture was stirred for $1 \mathrm{~h}$ in a nitrogen atmosphere. The resulting mixture was transferred dropwise to a cooled $\left(-10^{\circ} \mathrm{C}\right)$ solution of 4 -isopropylbenzyl bromide $(1.63 \mathrm{~mL}, 9.77 \mathrm{mmol})$ in THF $(10 \mathrm{~mL})$. Next the reaction mixture was allowed to warm to ambient temperature and stirred for $1 \mathrm{~h}$. The product was hydrolysed with saturated aqueous $\mathrm{NH}_{4} \mathrm{Cl}(15 \mathrm{~mL})$. The organic layer was extracted, dried over $\mathrm{MgSO}_{4}$ and filtered, and the solvent was removed in a vacuum to give rise to the product as an orange oil. The final product was obtained after purification by silica gel column chromatography using hexane:ethyl acetate 6:1. Yield: $45 \%$ (1.47 mg). ${ }^{1} \mathrm{H}$ NMR (400 MHz, $\left.\mathrm{CDCl}_{3}, 297 \mathrm{~K}\right), \delta(\mathrm{ppm}): 6.97$ (d, $J=7.5 \mathrm{~Hz}$, $2 \mathrm{H}, H^{1}$ 4-isopropylbenzyl), $6.80\left(\mathrm{~d}, J=7.5 \mathrm{~Hz}, 2 \mathrm{H}, H^{2}\right.$-isopropylbenzyl), $6.12\left(\mathrm{t}, J=7.1 \mathrm{~Hz}, 1 \mathrm{H}, \mathrm{CH}-\mathrm{CH}_{2}\right), 5.65$ (s, $2 \mathrm{H}, \mathrm{H}^{4}$ pyrazol), $3.78\left(\mathrm{~d}, J=7.1 \mathrm{~Hz}, 2 \mathrm{H}, \mathrm{CH}-\mathrm{CH}_{2}\right), 2.70\left(\mathrm{~m}, 1 \mathrm{H}, \mathrm{CH}-\left(\mathrm{CH}_{3}\right)_{2}\right), 2.14\left(\mathrm{~s}, 6 \mathrm{H}, \mathrm{CH}_{3}\right.$ pyrazol), 1.95 (s, 6H, CH $\mathrm{CH}_{3}$ pyrazol), $1.12\left(\mathrm{~d}, J=6.9 \mathrm{~Hz}, 6 \mathrm{H}, \mathrm{CH}-\left(\mathrm{CH}_{3}\right)_{2}\right) \cdot{ }^{13} \mathrm{C}\left\{{ }^{1} \mathrm{H}\right\}-\mathrm{NMR}\left(101 \mathrm{MHz}, \mathrm{CDCl}_{3}, 297 \mathrm{~K}\right), \delta(\mathrm{ppm})$ : $147.76,139.58$ (2C, quaternary pyrazol), 147.48, 133.93 (2C, quaternary 4-isopropylbenzyl), 129.25 (2C, $\mathrm{C}^{1}$ 4-isopropylbenzyl), 126.39 (2C, $\mathrm{C}^{2}$ 4-isopropylbenzyl), 106.36 (2C, $\mathrm{C}^{4}$ pyrazol), 72.57 (1C, $\mathrm{CH}^{-} \mathrm{CH}_{2}$ ), 39.51 (1C, $\left.\mathrm{CH}-\mathrm{CH}_{2}\right), 33.72\left(1 \mathrm{C}, \mathrm{CH}-\left(\mathrm{CH}_{3}\right)_{2}\right), 24.00\left(2 \mathrm{C}, \mathrm{CH}-\mathrm{CH}_{3}\right), 13.71\left(2 \mathrm{C}, \mathrm{CH}_{3}\right.$ pyrazol $), 10.94\left(2 \mathrm{C}, \mathrm{CH}_{3}\right.$ pyrazol). IR Neat: $\left.v_{\max } 2960.021 \mathrm{~cm}^{-1}(\mathrm{C}-\mathrm{H} \mathrm{sp})^{3}\right), 1556.294(\mathrm{C}=\mathrm{C}), 1511.367-1417.038 \mathrm{~cm}^{-1}$ (two bands, $\mathrm{C}-\mathrm{H}$ aromatic), $1378.809 \mathrm{~cm}^{-1}(\mathrm{C}=\mathrm{N})$; m.p: $356.15-358.15 \mathrm{~K}$.

Bacterial culture. Strains S. aureus ATCC25923, E. faecalis ATCC29212, E. coli ATCC25922, and P. aeruginosa ATCC27853 were used in all the microbiological studies. Unless otherwise stated, all the strains were cultured and maintained in Müller-Hinton broth solidified with 1.5\% agar. Before performing the antimicrobial activity assays, each bacterial strain was refreshed in $5 \mathrm{~mL}$ of Müller-Hinton broth separately under sterile conditions. Strains were cultured overnight at $37^{\circ} \mathrm{C}$ with $150 \mathrm{rpm}$ agitation in a shaking incubator. Each bacterial culture was maintained at a concentration of $10^{8}$ colony forming units (CFUs) $/ \mathrm{mL}$.

Determination of minimal inhibitory concentrations and minimal bactericidal concentrations. Minimum inhibitory concentrations (MICs) were determined using the previously reported broth microdilution method ${ }^{45}$. Briefly, a series of compounds concentrations starting from 2 to $1953 \mu \mathrm{g} / \mathrm{mL}$ at the two-fold dilution were added to the cation-adjusted Müller-Hinton broth (Sigma Aldrich, USA) (CAMHB) at a final volume of $100 \mu \mathrm{L}$ per well. One hundred microlitres of bacterial suspension in CAMHB containing approximately $1.6 \times 10^{6} \mathrm{CFU} / \mathrm{mL}$ were added to a Costar 96-well round-bottom polypropylene plate (Corning Inc., USA), followed by static incubation at $37{ }^{\circ} \mathrm{C}$ and $5 \% \mathrm{CO}_{2}$ for at least $20 \mathrm{~h}$. After incubation, MICs were determined by measuring absorbance at $600 \mathrm{~nm}$. A series of compound concentrations at the two-fold dilution and without bacteria was used as a negative control of absorbance. Minimum bactericidal concentrations 
(MBCs) were determined by the flash microbiocidal method described elsewhere ${ }^{46}$. Briefly after $24 \mathrm{~h}$ incubation, $10 \mu \mathrm{L}$ of each well were mixed with $190 \mu \mathrm{L}$ of tryptic soya broth (Biomérieux, France) in a new 96-well plate, which was incubated statically at $37^{\circ} \mathrm{C}$ and $5 \% \mathrm{CO}_{2}$ for $24 \mathrm{~h}$. After incubation, MBCs were determined by measuring absorbance at $600 \mathrm{~nm}$. These experiments were performed 4 times.

Minimal biofilm inhibitory concentrations and minimal biofilm eradication concentrations. Minimal biofilm inhibitory concentrations (MBIC) and minimal biofilm eradication concentrations (MBEC) were determined by the methodology described elsewhere ${ }^{47}$. For MBICs, biofilm formation on pegs from the Calgary device was induced by inoculating $200 \mu \mathrm{L}$ of tryptic soya broth containing $10^{6} \mathrm{CFU} / \mathrm{mL}$ per well in a 96-well flat-bottom plate (ThermoFisher Scientific, USA). Then the Calgary device lid (ThermoFisher Scientific, USA) was placed and the plate was incubated in turmoil at $37^{\circ} \mathrm{C}$ and $5 \% \mathrm{CO}_{2}$ for $24 \mathrm{~h}$. After incubation, the pegs from the lid were rinsed twice in the wells containing $200 \mu \mathrm{L}$ of phosphate buffered saline (PBS). Then the lid was placed in a plate at different compound concentrations starting from $2 \mathrm{mg} / \mathrm{mL}$ to $1953 \mu \mathrm{g} / \mathrm{mL}$ at the two-fold dilution to be added to CAMHB at a final volume of $200 \mu \mathrm{L}$ per well. It was incubated by static incubation at $37^{\circ} \mathrm{C}$ in $5 \% \mathrm{CO}_{2}$ for $24 \mathrm{~h}$.

After incubation, MBICs were determined by measuring absorbance at $600 \mathrm{~nm}$. A series of compound concentrations at the two-fold dilution and without bacteria was used as a negative control of absorbance. For MBECs, the lid from the MBIC was rinsed twice in a plate with wells containing $200 \mu \mathrm{L}$ of PBS, placed in a plate with $200 \mu \mathrm{L}$ of tryptic soya broth, and incubated by static incubation at $37^{\circ} \mathrm{C}$ and $5 \% \mathrm{CO}_{2}$ for $24 \mathrm{~h}$. After incubation, MBECs were determined by measuring absorbance at $600 \mathrm{~nm}$. These experiments were performed 4 times.

Cell line and culture conditions. Human liver carcinoma HepG2 (ATCC ${ }^{\circ}$ HB- $8065^{\mathrm{Tm}}$ ) and human colorectal adenocarcinoma Caco-2 (ATCC ${ }^{\circ}$ HTB- $37^{\mathrm{m}}$ ) cell lines were grown according to the standard protocol using DMEM $4.5 \mathrm{~g} / \mathrm{L}$ of glucose medium supplemented with $10 \%$ foetal bovine serum (FBS), penicillin and streptomy$\operatorname{cin}(100 \mu \mathrm{g} / \mathrm{mL})$ (all from Gibco ${ }^{\mathrm{rm}}$, Fischer Scientific), and cultured at $37^{\circ} \mathrm{C}$ in $5 \% \mathrm{CO}_{2}$.

Cell viability assays. Cells were plated in 96-well culture plates and cultured at $37{ }^{\circ} \mathrm{C}$ in $5 \% \mathrm{CO}_{2}$ for $24 \mathrm{~h}$. Then cells were washed twice with PBS, and $100 \mu \mathrm{L}$ of DMEM medium supplemented with $10 \%$ FBS, penicillin and streptomycin $(100 \mu \mathrm{g} / \mathrm{mL})$, were added to wells. Cells were treated with 500, 250, 125, $62.5 \mathrm{or} 31.25 \mu \mathrm{g} / \mathrm{mL}$ of the $2 \mathrm{P}$ nitrogen-based compound, and incubated at $37^{\circ} \mathrm{C}$ in $5 \% \mathrm{CO}_{2}$ for $48 \mathrm{~h}$. To determine toxicity by the 3-[4,5-dimethylthiazol-2-yl]-2,5-diphenyl tetrazolium bromide (MTT) assay, $10 \mu \mathrm{L}$ of MTT solution (Biotium, Quimigen) were added to each well following the manufacturer instructions ${ }^{48}$. Briefly, cells were incubated for $4 \mathrm{~h}$ and then $200 \mu \mathrm{L}$ of DMSO were added to each well. Absorbance was measured at $570 \mathrm{~nm}$ and $630 \mathrm{~nm}$ (background) in an iMark ${ }^{\mathrm{Tx}}$ Microplate Absorbance Reader (Bio-Rad) by subtracting background absorbance from signal absorbance to obtain normalised values. For the Resazurin viability assays, $10 \mu \mathrm{L}$ of Resazurin solution (Canvax Biotech) were added to each well by incubating cells for another 4 -h period. Next absorbance was measured at 545 and $620 \mathrm{~nm}$ (background) in a Multiescan EX Microplate Absorbance Reader (ThermoFisher Scientific) by subtracting background absorbance from signal absorbance to obtain normalised values. Photographs were taken on days 1 and 3 using a Zeiss Primovert inverted microscope with an Axiocam 208 colour camera at the 100-fold magnification.

pH study. Firstly, $250 \mu \mathrm{L}$ of the vehicle (Milli-Q Water) or $2 \mathrm{P}$ compound were added to $5 \mathrm{~mL}$ of DMEM medium ( $\mathrm{pH} 7.4$ ) to reach a final concentration of 0 or $500 \mu \mathrm{g} / \mathrm{mL}$ of the $2 \mathrm{P}$ compound, respectively. Then the treated mediums were incubated at $37^{\circ} \mathrm{C}$ in $5 \% \mathrm{CO}_{2}$, and the $\mathrm{pH}$ of solutions was measured at $0,6,24,48$ and $72 \mathrm{~h}$ using a $\mathrm{pH} 8+\mathrm{DHS}$ Stirrer $\mathrm{pH}$ meter (XS instruments). The $\mathrm{pH}$ studies were done in triplicate.

Statistical analysis. Statistical analysis was performed using the SPSS 13.0 (SPSS, Chicago, IL, USA). Mann-Whitney test or a non-parametric variance analysis (Kruskal-Wallis) followed by Dunn's test were used for the statistical analysis.

Received: 14 June 2021; Accepted: 27 July 2021

Published online: 11 August 2021

\section{References}

1. Bassetti, M., Merelli, M., Temperoni, C. \& Astilean, A. New antibiotics for bad bugs: Where are we?. Ann. Clin. Microbiol. Antimicrob. 12, 22 (2013).

2. Poulakou, G., Bassetti, M., Righi, E. \& Dimopoulos, G. Current and future treatment options for infections caused by multidrugresistant Gram-negative pathogens. Future Microbiol. 9, 1053-1069 (2014).

3. Wencewicz, T. A. Crossroads of antibiotic resistance and biosynthesis. J. Mol. Biol. 431, 3370-3399 (2019).

4. Hutchings, M. I., Truman, A. W. \& Wilkinson, B. Antibiotics: Past, present and future. Curr. Opin. Microbiol. 51, 72-80 (2019).

5. Rodrigues, C. et al. KPC-3-producing Klebsiella pneumoniae in Portugal linked to previously circulating Non-CG258 lineages and uncommon genetic platforms (Tn4401d-IncFIA and Tn4401d-IncN). Front. Microbiol. 7, 1000 (2016).

6. Allahverdiyev, A. M., Kon, K. V., Abamor, E. S., Bagirova, M. \& Rafailovich, M. Coping with antibiotic resistance: Combining nanoparticles with antibiotics and other antimicrobial agents. Expert Rev. Anti Infect. Ther. 9, 1035-1052 (2011).

7. Thorpe, K. E., Joski, P. \& Johnston, K. J. Antibiotic-resistant infection treatment costs have doubled since 2002, now exceeding $\$ 2$ billion annually. Health Aff. 37, 662-669 (2018). 
8. Ju, J. et al. Application of starch microcapsules containing essential oil in food preservation. Crit. Rev. Food Sci. Nutr. 60, 2825-2836 (2020).

9. Roy, A., Gauri, S. S., Bhattacharya, M. \& Bhattacharya, J. Antimicrobial activity of $\mathrm{CaO}$ nanoparticles. J. Biomed. Nanotechnol. 9 , 1570-1578 (2013).

10. Sakkas, H. \& Papadopoulou, C. Antimicrobial activity of basil, oregano, and thyme essential oils. J. Microbiol. Biotechnol. 27, 429-438 (2017).

11. Pop, C. S. et al. Metallic-based micro- and nanostructures with antimicrobial activity. Curr. Top. Med. Chem. 15, 1577-1582 (2015).

12. Aguilera-Correa, J. J., Esteban, J. \& Vallet-Regí, M. Inorganic and polymeric nanoparticles for human viral and bacterial infections prevention and treatment. Nanomaterials 11, 137 (2021).

13. Deva, A. K., Adams, W. P. Jr. \& Vickery, K. The role of bacterial biofilms in device-associated infection. Plast. Reconstr. Surg. 132, 1319-1328 (2013).

14. Tung, T. T. \& Quoc, T. N. Discovery of novel $\beta$-turn mimetic-based peptides as novel quorum sensing inhibitors of gram-negative bacteria. Bioorg. Med. Chem. Lett. 46, 128170 (2021).

15. Nam, S. et al. Discovery and characterization of pure RhlR antagonists against Pseudomonas aeruginosa infections. J. Med. Chem. 63, 8388-8407 (2020).

16. Linciano, P. et al. Tackling antimicrobial resistance with small molecules targeting LsrK: Challenges and opportunities. J. Med. Chem. 63, 15243-15257 (2020).

17. Otero, A. et al. Versatile scorpionates and new developments in the denticity changes of NNCp hybrid scorpionate/cyclopentadienyl ligands in Sc and Y compounds: From kappa1-Neta5-Cp to kappa2-NNeta5-Cp. Inorg. Chem. 47, 4996-5005 (2008).

18. Zeimentz, P. M., Arndt, S., Elvidge, B. R. \& Okuda, J. Cationic organometallic complexes of scandium, yttrium, and the lanthanoids. Chem. Rev. 106, 2404-2433 (2006).

19. Castro-Osma, J. A. et al. An efficient and tunable route to bis(1,2,3-triazol-1-yl)methane-based nitrogen compounds. Eur. J. Org. Chem. 4, 682-687 (2016).

20. Otero, A., Fernández-Baeza, J., Lara-Sánchez, A. \& Sánchez-Barba, L. Metal complexes with heteroscorpionate ligands based on the bis(pyrazol-1-yl)methane moiety: Catalytic chemistry. F Coord. Chem. Rev. 257, 1806-1868 (2013).

21. Keisers, K. et al. Interplay of spin crossover and coordination-induced spin state switch for iron bis(pyrazolyl)methanes in solution. Inorg. Chem. 59, 15343-15354 (2020).

22. Castro-Osma, J. A. et al. Catalytic behaviour in the ring-opening polymerisation of organoaluminiums supported by bulky heteroscorpionate ligands. Dalton Trans. 44, 12388-12400 (2015).

23. Fayaz, A. M. et al. Biogenic synthesis of silver nanoparticles and their synergistic effect with antibiotics: A study against grampositive and gram-negative bacteria. Nanomedicine 6, 103-109 (2010).

24. Marchese, A. et al. Update on monoterpenes as antimicrobial agents: A particular focus on p-cymene. Materials (Basel) 10, 947 (2017).

25. Stoor, P., Soderling, E. \& Grenman, R. Bioactive glass S53P4 in repair of septal perforations and its interactions with the respiratory infection-associated microorganisms Haemophilus influenzae and Streptococcus pneumoniae. J. Biomed. Mater. Res. 58, 113-120 (2001).

26. Lepparanta, O. et al. Antibacterial effect of bioactive glasses on clinically important anaerobic bacteria in vitro. J. Mater. Sci. Mater. Med. 19, 547-551 (2008).

27. Nessim, S. J., Nisenbaum, R., Bargman, J. M. \& Jassal, S. V. Microbiology of peritonitis in peritoneal dialysis patients with multiple episodes. Perit. Dial. Int. 32, 316-321 (2012).

28. van Diepen, A. T., Tomlinson, G. A. \& Jassal, S. V. The association between exit site infection and subsequent peritonitis among peritoneal dialysis patients. Clin. J. Am. Soc. Nephrol. 7, 1266-1271 (2012).

29. Sondi, I. \& Salopek-Sondi, B. Silver nanoparticles as antimicrobial agent: A case study on E. coli as a model for Gram-negative bacteria. J. Colloid Interface Sci. 275, 177-182 (2004).

30. Monteiro, D. R. et al. The growing importance of materials that prevent microbial adhesion: Antimicrobial effect of medical devices containing silver. Int. J. Antimicrob. Agents 34, 103-110 (2009).

31. Churklam, W., Chaturongakul, S., Ngamwongsatit, B. \& Aunpad, R. The mechanisms of action of carvacrol and its synergism with Nisin against Listeria monocytogenes on sliced bologna sausage. Food Control 108, 106864 (2020).

32. Ait-Ouazzou, A. et al. New insights in mechanisms of bacterial inactivation by carvacrol. J. Appl. Microbiol. 114, 173-185 (2013).

33. Nishio, K. et al. Extracellular electron transfer across bacterial cell membranes via a cytocompatible redox-active polymer. ChemPhysChem 14, 2159-2163 (2013).

34. Schaffer, C. \& Messner, P. The structure of secondary cell wall polymers: How Gram-positive bacteria stick their cell walls together. Microbiology 151, 643-651 (2005).

35. Kawabata, N. \& Nishiguchi, M. Antibacterial activity of soluble pyridinium-type polymers. Appl. Environ. Microbiol. 54, 2532-2535 (1988).

36. Taylor, E. \& Webster, T. J. Reducing infections through nanotechnology and nanoparticles. Int. J. Nanomed. 6, 1463-1473 (2011).

37. Hu, S., Chang, J., Liu, M. \& Ning, C. Study on antibacterial effect of 45S5 Bioglass. J. Mater. Sci. Mater. Med. 20, 281-286 (2009).

38. Nostro, A. et al. Effect of alkaline $\mathrm{pH}$ on staphylococcal biofilm formation. APMIS 120, 733-742 (2012).

39. Perez-Tanoira, R. et al. Effect of S53P4 bone substitute on staphylococcal adhesion and biofilm formation on other implant materials in normal and hypoxic conditions. J. Mater. Sci. Mater. Med. 26, 239 (2015).

40. Ozdemir, A., Turan-Zitouni, G., Kaplancikli, Z. A., Revial, G. \& Güven, K. Synthesis and antimicrobial activity of 1-(4-aryl-2thiazolyl)-3-(2-thienyl)-5-aryl-2-pyrazoline derivatives. Eur. J. Med. Chem. 42, 403-409 (2007).

41. Lass-Flörl, C. Triazole antifungal agents in invasive fungal infections: A comparative review. Drugs 71, 2405-2419 (2011).

42. Slavin, M. A. et al. Efficacy and safety of fluconazole prophylaxis for fungal infections after marrow transplantation-a prospective, randomized, double-blind study. J. Infect. Dis. 171, 1545-1552 (1995).

43. Davis, C. M. \& Curran, K. A. Manipulation of a Schlenk line: Preparation of tetrahydrofuran complexes of transition-metal chlorides. J. Chem. Educ. 84, 1822-1823 (2007).

44. Díez-Barra, E., de la Hoz, A., Sánchez-Migallon, A. \& Tejeda, J. Selective lithiation of bis(azol-1-yl)methanes. Chem. Soc. Perkin Trans. 1, 1079-1083 (1993).

45. Lu, J., Liong, M., Li, Z., Zink, J. I. \& Tamanoi, F. Biocompatibility, biodistribution, and drug-delivery efficiency of mesoporous silica nanoparticles for cancer therapy in animals. Small 6, 1794-1805 (2010).

46. Hernandes, C., da Silva Coppede, J., Bertoni, B. W., de Castro França, S. \& Soares Pereira, A. M. Flash microbiocide: A rapid and economic method for determination of MBC and MFC. Am. J. Plant Sci. 4, 850-852 (2013).

47. Ceri, H. et al. The Calgary biofilm device: New technology for rapid determination of antibiotic susceptibilities of bacterial biofilms. J. Clin. Microbiol. 37, 1771-1776 (1999).

48. Ortega, A. et al. Antimicrobial evaluation of quaternary ammonium polyethyleneimine nanoparticles against clinical isolates of pathogenic bacteria. IET Nanobiotechnol. 9, 342-348 (2015). 


\section{Acknowledgements}

We gratefully acknowledge financial support from the Ministerio de Economía y Competitividad (MINECO), Spain (Grant Nos. CTQ2017-84131-R and CTQ2016-81797-REDC Programa Redes Consolider). Elena Domínguez-Jurado acknowledges the University of Castilla-La Mancha for her Fellowship.

\section{Author contributions}

P.S; J.J.A.-C.; C.M.S.-L.; C.A.-M.; F.C.P.-M.; and M.M.-A. wrote the main manuscript text. E.D.-J.; J.A.C.-O.; and C.A.-M. have synthetized the compounds and prepared their figures. A.V.O.; M.M.-A.; C.M.S.-L.; and A.M. have done toxicity assays and prepared their figures. F.C.P.-M.; P.S.; J.J.A.-C.; R.P.-T.; and J.E. have done microbiological studies and prepared their figures. All authors reviewed the manuscript.

\section{Competing interests}

The authors declare no competing interests.

\section{Additional information}

Supplementary Information The online version contains supplementary material available at https://doi.org/ 10.1038/s41598-021-95609-z.

Correspondence and requests for materials should be addressed to F.C.P.-M.

Reprints and permissions information is available at www.nature.com/reprints.

Publisher's note Springer Nature remains neutral with regard to jurisdictional claims in published maps and institutional affiliations.

(c) (i) Open Access This article is licensed under a Creative Commons Attribution 4.0 International License, which permits use, sharing, adaptation, distribution and reproduction in any medium or format, as long as you give appropriate credit to the original author(s) and the source, provide a link to the Creative Commons licence, and indicate if changes were made. The images or other third party material in this article are included in the article's Creative Commons licence, unless indicated otherwise in a credit line to the material. If material is not included in the article's Creative Commons licence and your intended use is not permitted by statutory regulation or exceeds the permitted use, you will need to obtain permission directly from the copyright holder. To view a copy of this licence, visit http://creativecommons.org/licenses/by/4.0/.

(C) The Author(s) 2021 